\section{(6) OPEN ACCESS}

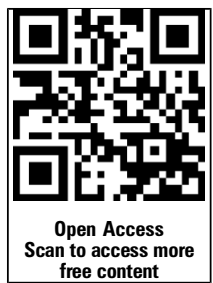

- Additional material is published online only. To view please visit the journal online (http://dx.doi.org/10.1136/ jmedgenet-2015-103471)

${ }^{1}$ Division of Nephrology, Department of Medicine, University of Alabama at Birmingham, Birmingham, Alabama, USA

${ }^{2}$ Department of Internal Medicine, University of lowa Carver College of Medicine, lowa City, lowa, USA ${ }^{3}$ General Hospital, Slovenj Gradec, Slovenia

${ }^{4}$ Department of Medicine, Medical University of South Caroline, Charleston, South Carolina, USA

${ }^{5}$ Departments of PediatricsGenetics, Northwestern University Feinberg School of Medicine and Ann \& Robert $H$. Lurie Children's Hospital of Chicago, Chicago, Illinois, USA ${ }^{6}$ Department of Human Genetics, Emory University, Atlanta, Georgia, USA ${ }^{7}$ Department of Nephrology, University Klinik Würzburg Würzburg, Germany

\section{Correspondence to} Dr David G Warnock, Room 614 ZRB, UAB, 1720 2nd Avenue South, Birmingham, AL 34294-0007, USA dwarnock@uab.edu

Received 22 August 2015 Accepted 25 September 2015 Published Online First 21 October 2015

\section{CrossMark}

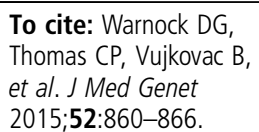

\title{
Antiproteinuric therapy and Fabry nephropathy: factors associated with preserved kidney function during agalsidase-beta therapy
}

\author{
David G Warnock, ${ }_{1}^{1}$ Christie P Thomas, ${ }^{2}$ Bojan Vujkovac, ${ }_{1}^{3}$ Ruth C Campbell, ${ }_{1}^{4}$ \\ Joel Charrow, ${ }^{5}$ Dawn A Laney, ${ }^{6}$ Leslie L Jackson, ${ }^{1}$ William R Wilcox, ${ }^{6}$ \\ Christoph Wanner ${ }^{7}$
}

ABSTRACT

Background Nephropathy is an important feature of classical Fabry disease, which results in alpha-galactosidase A deficiency and cellular globotriaosylceramide accumulation. We report the safety and efficacy of antiproteinuric therapy with ACE inhibitors or angiotensin II receptor blockers (ARBs) in a study of classical Fabry patients receiving recombinant agalsidase-beta therapy.

Methods and design The goal was maintenance of urine protein to creatinine ratio (UPCR) $<0.5 \mathrm{~g} / \mathrm{g}$ or a $50 \%$ reduction in baseline UPCR for 24 patients at eight study sites. The change in estimated glomerular filtration rate (eGFR) was assessed over 21 months of treatment. Results 18 out of 24 patients achieved the UPCR goal with eGFR slopes that were significantly better than six patients who did not achieve the UPCR goal $(-3.6$ $(-4.8$ to -1.1$)$ versus $-7.0(-9.0$ to -5.6$) \mathrm{mL} / \mathrm{min} /$ $1.73 \mathrm{~m}^{2} /$ year, respectively, $\left.\mathrm{p}=0.018\right)$. Despite achieving the UPCR goal, 67\% (12/18 patients) still progressed with an eGFR slope $<-2 \mathrm{~mL} / \mathrm{min} / 1.73 \mathrm{~m}^{2} /$ year. Regression analysis showed that increased age at initiation of agalsidase-beta therapy was significantly associated with worsened kidney outcome. Hypotension and hyperkalaemia occurred in seven and eight patients, respectively, which required modification of antiproteinuric therapy but was not associated with serious adverse events.

Conclusions This study documents the effectiveness of agalsidase-beta (1 mg/kg/2 weeks) and antiproteinuric therapy with ACE inhibitors and/or ARB in patients with severe Fabry nephropathy. Patients had preservation of kidney function if agalsidase-beta treatment was initiated at a younger age, and UPCR maintained at or below $0.5 \mathrm{~g} / \mathrm{g}$ with antiproteinuric therapy. Trial registration number NCT00446862.

\section{INTRODUCTION}

Fabry disease (OMIM \#301500) is an X-linked disorder caused by lysosomal alpha-galactosidase A ( $\alpha$-Gal A) deficiency. Classical patients with mutations in the $\alpha$-Gal A gene accumulate globotriaosylceramide (GL-3) and become symptomatic in childhood with pain, gastrointestinal disturbances, angiokeratoma and hypohidrosis. ${ }^{1}$ Classical patients experience progressive loss of renal function and hypertrophic cardiomyopathy, with severe clinical events including end-stage renal disease, stroke, arrhythmias and premature death. ${ }^{12}$ Heterozygous women may be affected as severely as male Fabry patients, ${ }^{2-4}$ especially with skewed X-chromosome inactivation. ${ }^{56}$

Enzyme replacement therapy (ERT) and supportive care (eg, renal replacement therapy) have changed the natural history of Fabry disease; cardiovascular events now account for the majority of deaths. ${ }^{7}$ Agalsidase-beta given at $1 \mathrm{mg} / \mathrm{kg}$ every two weeks reduced endothelial GL-3 deposits from kidney, skin and heart biopsies in a randomised, placebo-controlled phase III trial with 58 patients. ${ }^{9}{ }^{10}$ In an open-label, 54-month extension study, renal function was stabilised in most patients. ${ }^{11}$ However, baseline proteinuria $(>1 \mathrm{~g} /$ $24 \mathrm{~h}$ ) and $>50 \%$ glomerulosclerosis on kidney biopsies were important risk factors for continued loss of renal function despite ERT. ${ }^{11}$ With an additional 5 years of follow-up, patients who maintained urinary protein-to-creatinine ratios (UPCR) $<0.5 \mathrm{~g} / 24 \mathrm{~h}$ on agalsidase-beta had low risk for renal progression, while those with UPCR $>0.5 \mathrm{~g} /$ $24 \mathrm{~h}$ had progressive loss of renal function. ${ }^{12}$ Mean estimated glomerular filtration rate (eGFR) slopes for the two groups were -1.89 and $-6.82 \mathrm{~mL} / \mathrm{min} /$ $1.73 \mathrm{~m}^{2} /$ year, respectively. ${ }^{12}$ The age at which patients started agalsidase-beta emerged as an important factor that differentiated the two groups (mean 25 vs 38 years, respectively).

Another randomised, placebo-controlled study with agalsidase-beta was conducted with Fabry patients and more advanced renal involvement (baseline eGFR $<80 \mathrm{~mL} / \mathrm{min} / 1.73 \mathrm{~m}^{2} /$ year). ${ }^{13}$ The overall results were similar for the two randomised studies; patients with higher baseline eGFR and lower UPCR had significant preservation of renal function when treated with agalsidase-beta. ${ }^{11-13}$ We previously demonstrated in a small, open-label single-centre study that treatment with ACE inhibitors or angiotensin receptor blocker (ARB) to maintain UPCR $<0.5 \mathrm{~g} / 24 \mathrm{~h}$ was associated with stabilisation of renal function even in Fabry patients at high risk for progression of nephropathy. ${ }^{14}$ This background provides the rationale for prospectively evaluating the control of proteinuria in Fabry nephropathy.

The objective of the present study was to investigate the safety and efficacy of antiproteinuric therapy with ACE inhibitor and/or ARB therapy in adults with Fabry nephropathy. We hypothesised that patients with UPCR maintained $<0.5 \mathrm{~g} / \mathrm{g}$ 
throughout the study would have preservation of their renal function. Participants over 21 months in 24 patients $(15$ males and 9 females) with classic Fabry disease treated with agalsidasebeta at eight different study sites. Also, 18 of the 24 participants achieved the UPCR goal during the study, but only 6 out of 18 had preservation of kidney function (eGFR slopes better than $-2.0 \mathrm{~mL} / \mathrm{min} / 1.73 \mathrm{~m}^{2} /$ year). The age at which agalsidase-beta was started was the most significant factor associated with loss of kidney function despite control of UPCR to the defined treatment goal of $0.5 \mathrm{~g} / \mathrm{g}$ or $50 \%$ reduction from the baseline level.

\section{METHODS}

Study design, participants and setting

The Fabrazyme+Arbs+ACE inhibitor Treatment (FAACET) study evaluated the safety and efficacy proteinuria control with ACE inhibitor and/or ARB therapy Fabry patients who were receiving ERT with agalsidase-beta at $1 \mathrm{mg} / \mathrm{kg}$ every two weeks. FAACET was registered as a prospective observational study (NCT00446862), sponsored by the University of Alabama at Birmingham. Enrolment was based on local study site records, and included adult males and females with Fabry nephropathy associated with reduced eGFR and/or significant proteinuria. After a 3-month initial baseline phase, the patients were followed during a 21-month treatment phase. The primary objective (UPCR goal) was reduction of the UPCR to $<0.5 \mathrm{~g} / \mathrm{g}$ for all treatment visits or the averaged treatment UPCR values to $<50 \%$ of the first baseline value. ACE inhibitor and/or ARB doses were adjusted during the visits according to the local standards for care, with the goal of reaching and maintaining the UPCR goal. The primary outcome measure was the regression slope of eGFR (mL/min/1.73 $\mathrm{m}^{2} /$ year).

The inclusion criteria included ethics committee-approved, written informed consent at each study site for adults $(\geq 19$ years of age) with classical Fabry disease who were already receiving agalsidase-beta at the first visit. Patients qualified with eGFR $\geq 20$ and $\leq 60 \mathrm{~mL} / \mathrm{min} / 1.73 \mathrm{~m}^{2}$ and documented UPCR $>0.5 ;$ or eGFR $\leq 125 \mathrm{~mL} / \mathrm{min} / 1.73 \mathrm{~m}^{2}$ and $>60 \mathrm{~mL} / \mathrm{min} /$ $1.73 \mathrm{~m}^{2}$ with documented UPCR $>1.0$. These qualifications were based on previous descriptions of patients with Fabry disease for whom the rate of loss of kidney function was related to their baseline urine protein and kidney function. ${ }^{15}{ }^{16}$ Many patients were already receiving ACE inhibitor or ARB therapy at the time of enrolment and were not removed from these agents before enrolment. A parallel placebo-treated arm was not included in the FAACET study design. Exclusion criteria were prior end-stage renal disease and/or renal transplantation; presence of another confounding kidney disease demonstrated by renal biopsy; and documented allergies to any of the treatment agents, pregnancy or potential pregnancy during the study period.

\section{Statistical analysis}

The primary efficacy analysis was the change in renal function assessed as eGFR slope stratified by the UPCR goal, to assess the impact of ACE inhibitor/ARB therapy on decline of eGFR in patients receiving agalsidase-beta therapy. A medication score was used to describe the intensity of antiproteinuric and antihypertensive medication at the last visit. This score was defined as 0 , none; 1, ACE inhibitor or ARB; 2, ACE inhibitor plus ARB, or either with diuretic; 3, ACE inhibitor or ARB at maximum dose. The Chronic Kidney Disease Epidemiology Collaboration equation was used to calculate estimated GFR based on serum creatinine measured at each visit. ${ }^{17}$ All serum creatinine measurements were performed in the UAB Hospital Central
Laboratory using isotope-dilution mass-spectroscopy traceable calibration. ${ }^{18}$

We compared characteristics of patients using $\chi^{2}$ and analysis of variance. Duncan and Dunnett tests were used for multiple comparisons, with statistical significance set at $p \leq 0.05$. Values are presented as $\pm 1 \mathrm{SD}$; median values are presented with 25 th and 75 th centiles (IQR). The eGFR slopes and intercepts were calculated with linear regression for individual patient treatment visits, and patient-specific intercepts and slopes were extracted from mixed effect linear regression models for the entire group. Statistical and graphical analyses were done with Stata V.13.1 (Stata, College Station, Texas, USA).

\section{RESULTS}

\section{Characteristics at qualification and baseline evaluation}

Thirty-two subjects were enrolled at 10 different study sites, and 24 subjects ( 15 males and 9 females) completed the study protocol. The study sites, principal investigators, number of subjects enrolled, number of subjects completing the protocol and reasons for discontinuation are shown in online supplementary table 1 . For the 24 subjects who completed the study, the baseline median age was 43.1 years (IQR 38.3-50.2); 15 were males and 3 self-identified themselves as black (table 1).

The median duration of ERT therapy before the first visit was 3.1 years (IQR 0.3-4.4), and the median age at which ERT was started was 42.8 years (IQR 36.1-47.5). Median values for qualifying UPCR (1.5 g/g (IQR 1.1-2.3)) and eGFR $(71 \mathrm{~mL} /$ $\mathrm{min} / 1.73 \mathrm{~m}^{2}$ (IQR 56-95)) were obtained 1.0 year (IQR $0.1-$ 2.2) before enrolment. Baseline values for vital signs, serum potassium, UPCR, albumin to creatinine ratio (ACR) and eGFR are also listed in table 1 . The historical eGFR slope (difference between baseline and qualifying eGFR values divided by the interval) was estimated at $-6.2 \mathrm{~mL} / \mathrm{min} / 1.73 \mathrm{~m}^{2} /$ year for 12 subjects with intervals $>12$ months. Historical estimates were not calculated for subjects if data were not available 12 months before enrolment.

The baseline clinical findings are summarised in online supplementary table 2 for the 24 participants who completed the study. The FAACET participants had cardiac involvement and significant kidney involvement based on the qualifying thresholds for UPCR and eGFR. At the time of the first visit, 22 of 24 patients were already receiving ACE inhibitors and/or ARBS.

\section{Titration and maintenance of UPCR goal}

The primary objective of the FAACET study was reduction of the UPCR to $<0.5 \mathrm{~g} / \mathrm{g}$ for all treatment visits or the averaged treatment UPCR values to $<50 \%$ of the first baseline value. The characteristics are shown in table 1 for the 24 FAACET study participants, stratified by UPCR goal. The antiproteinuric doses were adjusted during the baseline and treatment visits, following the local standards of care, to achieve and maintain the UPCR goal. The baseline values for participants stratified by the UPCR goal are shown in table 1 . The average values for the treatment visits were similar for the group of 18 participants who met the UPCR goal. The baseline systolic blood pressure and ACR values were higher for the six participants who did not reach the UPCR goal.

The results for UPCR and ACR throughout the treatment visits are shown in figure $1 \mathrm{~A}$ stratified by UPCR goal. Participants who met the UPCR goal at the first treatment visit remained close to goal throughout the study. Participants above UPCR goal at the first treatment visit were not successfully titrated to goal during the three baseline visits and remained above the UPCR goal throughout the remaining treatment visits. 
Table 1 Baseline characteristics for all participants completing titration and follow-up visits: stratified by urine protein to creatinine ratio goal

\begin{tabular}{|c|c|c|c|}
\hline Variable & Total & Met UPCR goal & Above UPCR goal \\
\hline Participants (n) & $24(100 \%)$ & $18(75 \%)$ & $6(24 \%)$ \\
\hline Age at baseline (years) & $43.1(39.5-46.7)$ & $43.6(39.4-47.8)$ & $41.7(31.9-51.1)$ \\
\hline Males & $15(63 \%)$ & $10(56 \%)$ & $5(83 \%)$ \\
\hline Blacks & $3(13 \%)$ & $2(11 \%)$ & $1(17 \%)$ \\
\hline Duration on agalsidase-beta (years) & $3.1(0.3-4.4)$ & $2.9(0.3-4.8)$ & $3.6(1.4-4.1)$ \\
\hline Agalsidase-beta started at age (years) & $42.8(36.1-47.5)$ & $43.3(38.0-47.9)$ & $37.2(33.5-47.2)$ \\
\hline \multicolumn{4}{|l|}{ Qualification values (historical data) } \\
\hline Urine protein-creatinine ratio $(\mathrm{g} / \mathrm{g})$ & $1.5(1.1-2.3)$ & $1.4(1.0-2.3)$ & $1.9(1.5-2.3)$ \\
\hline eGFR $\left(\mathrm{mL} / \mathrm{min} / 1.73 \mathrm{~m}^{2}\right)$ & $71(56-93)$ & $71(55-94)$ & $73(56-92)$ \\
\hline Interval before enrolment (years) & $1.0(0.1-2.2)$ & $0.6(0.1-1.6)$ & $2.2(1.8-2.4)$ \\
\hline \multicolumn{4}{|l|}{ Initial baseline values (visit-3) } \\
\hline Systolic blood pressure $(\mathrm{mm} \mathrm{Hg})$ & $112(103-128)$ & $110(100-130)$ & $119(112-121)$ \\
\hline Diastolic blood pressure $(\mathrm{mm} \mathrm{Hg})$ & $73(64-77)$ & $72(63-82)$ & $73(68-75)$ \\
\hline Serum potassium (mEq/L) & $4.2(4.0-4.5)$ & $4.2(4.1-4.4)$ & $4.0(3.8-4.9)$ \\
\hline Urine protein-creatinine ratio $(\mathrm{g} / \mathrm{g})$ & $0.7(0.4-1.3)$ & $0.6(0.3-1.1)$ & $1.2(0.4-2.3)$ \\
\hline Urine albumin-creatinine ratio $(\mathrm{mg} / \mathrm{g})$ & $263(73-759)$ & $124(49-555)$ & 759 (459-1398) \\
\hline eGFR $\left(\mathrm{mL} / \mathrm{min} / 1.73 \mathrm{~m}^{2}\right)$ & $69(53-93)$ & $69(56-92)^{a}$ & $62(46-93)$ \\
\hline Historical eGFR slope (N) (mL/min/1.73 $\mathrm{m}^{2} /$ year;) $\mathrm{N}=12$ & $-6.2(12)(-8.4$ to -2.7$)$ & $-7.1(7)(-9.3$ to -5.4$)$ & -3.2 (5) $(-6.9$ to -2.3$)$ \\
\hline \multicolumn{4}{|l|}{ Averaged treatment values } \\
\hline Systolic blood pressure (mm Hg) & $112(104-124)$ & $112(103-127)$ & $112(107-117)$ \\
\hline Diastolic blood pressure (mm Hg) & $71(63-73)$ & $71(62-78)$ & $70(64-73)$ \\
\hline Serum potassium (mEq/L) & $4.4(3.9-4.7)$ & $4.4(4.0-4.7)$ & $4.3(3.8-4.9)$ \\
\hline UPCR $(g / g)$ & $0.5(0.3-0.9)$ & $0.4(0.2-0.5)$ & $0.9(0.7-1.5)$ \\
\hline ACR $(\mathrm{mg} / \mathrm{g})$ & $267(123-637)$ & $226(81-365)$ & $579(454-733)$ \\
\hline eGFR $\left(\mathrm{mL} / \mathrm{min} / 1.73 \mathrm{~m}^{2}\right)$ & $65(44-83)$ & $67(48-83)$ & $46(40-78)$ \\
\hline
\end{tabular}

Figure $1 \mathrm{~B}$ shows the UPCR ratios for participants stratified by the eGFR intercept at $60 \mathrm{~mL} / \mathrm{min} / 1.73 \mathrm{~m}^{2}$. Participants who were in the eGFR strata $<60 \mathrm{~mL} / \mathrm{min} / 1.73 \mathrm{~m}^{2}$ had higher UPCR values throughout the treatment visits.

\section{Stratification by UPCR goal and eGFR slopes}

Table 2 shows the eGFR slopes stratified by UPCR categories. The slopes and intercepts were calculated for each strata using mixed-effects linear regression analysis, and the linear slopes were obtained from linear regression analysis of individual patient data.

The average eGFR slope for 13 participants with initial UPCR values $\leq 0.5 \mathrm{~g} / \mathrm{g}$ was $-3.42 \mathrm{~mL} / \mathrm{min} / 1.73 \mathrm{~m}^{2} /$ year (SD 2.30), the eGFR slope for six participants with initial UPCR values $>0.5$ and $\leq 1.0 \mathrm{~g} / \mathrm{g}$ was $-4.86 \mathrm{~mL} / \mathrm{min} / 1.73 \mathrm{~m}^{2} /$ year (SD 3.27) and for five participants with initial UPCR values
Figure 1 Box plots of urine protein to creatinine ratio (UPCR). (A) Stratified at UPCR goal. (B) Stratified by Chronic Kidney Disease Epidemiology Collaboration estimated glomerular filtration rate (eGFR) intercept at $60 \mathrm{~mL} / \mathrm{min}$ per $1.73 \mathrm{~m}^{2}$. The UPCR goal was defined as UPCR for first treatment visit $\leq 0.5 \mathrm{~g} / \mathrm{g}$ or averaged treatment UPCR $\leq 50 \%$ of baseline UPCR (visit -3). The eGFR intercept was calculated with a mixed-effect linear model across all treatment visits. eGFR slopes, $\mathrm{mL} / \mathrm{min} / 1.73 \mathrm{~m}^{2} /$ year. The horizontal line is the median value and the upper and lower limits of the boxes are 75 th and 25 th centiles, respectively. The number of participants in each category is shown in parentheses above the upper cap of the 90 th centile values.

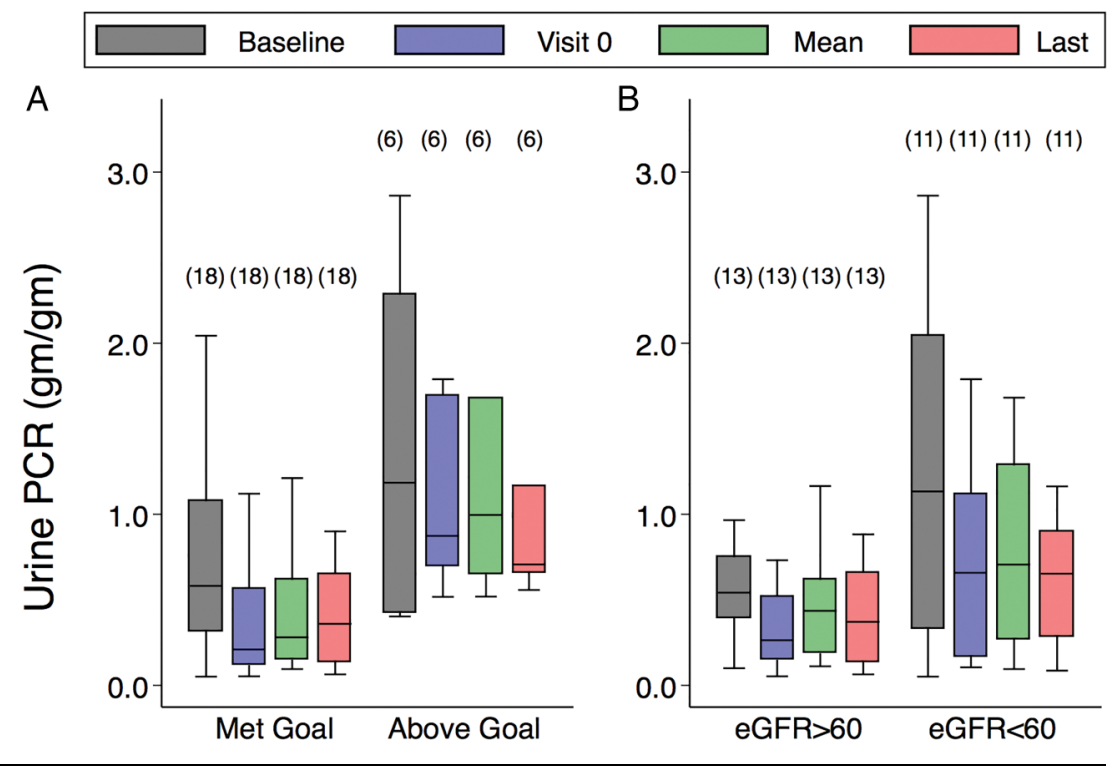

Warnock DG, et al. J Med Genet 2015;52:860-866. doi:10.1136/jmedgenet-2015-103471 
Table 2 Estimated glomerular filtration slopes and intercepts by urine protein to creatinine strata

\begin{tabular}{|c|c|c|c|c|c|c|c|}
\hline \multirow[b]{3}{*}{ Sex (F/M) } & \multirow[b]{3}{*}{ UPCR strata } & \multicolumn{2}{|c|}{ Initial values } & \multicolumn{4}{|l|}{ Treatment values } \\
\hline & & \multirow[b]{2}{*}{ eGFR } & \multirow[b]{2}{*}{ UPCR } & \multirow[b]{2}{*}{ Averaged UPCR } & \multicolumn{2}{|c|}{ Mixed models } & \multirow[b]{2}{*}{ Linear slope } \\
\hline & & & & & Intercept & Slope & \\
\hline $6 / 7$ & $\leq 0.5$ & $70 \pm 30$ & $0.33 \pm 0.37$ & $0.29 \pm 0.15$ & $70 \pm 28$ & $-3.42 \pm 2.30$ & $-1.03 \pm 6.15$ \\
\hline $1 / 5$ & $0.5-1.0$ & $66 \pm 31$ & $0.71 \pm 0.30$ & $0.73 \pm 0.19$ & $65 \pm 24$ & $-4.86 \pm 3.27$ & $-3.77 \pm 7.60$ \\
\hline $2 / 3$ & $>1.0$ & $76 \pm 23$ & $1.2 \pm 0.8$ & $1.5 \pm 0.5$ & $76 \pm 28$ & $-5.27 \pm 6.00$ & $-6.81 \pm 11.7$ \\
\hline
\end{tabular}

$>1.0 \mathrm{~g} / \mathrm{g}$ was $-5.27 \mathrm{~mL} / \mathrm{min} / 1.73 \mathrm{~m}^{2} /$ year (SD 6.00); these slopes were not significantly different for the UPCR strata.

Figure $2 \mathrm{~A}$ shows the eGFR slopes $\left(-3.6 \mathrm{~mL} / \mathrm{min} / 1.73 \mathrm{~m}^{2} /\right.$ year (95\% CI -4.8 to -1.1$)$ ) for 18 participants who met the prespecified UPCR goal, while the eGFR slope for those who did not meet the UPCR goal was $-7.0 \mathrm{~mL} / \mathrm{min} / 1.73 \mathrm{~m}^{2} /$ year $(95 \% \mathrm{CI}$ -5.6 to -2.0$)$; this $49 \%$ difference was statistically significant $(p=0.005)$, and the slopes were significantly from zero $(\mathrm{p}=0.001$ and 0.018 , respectively).

The median eGFR slope in figure 2B (shaded box) was -0.1 (95\% CI -1.1 to 1.3 ) $\mathrm{mL} / \mathrm{min} / 1.73 \mathrm{~m}^{2} /$ year for the six participants who met UPCR goal and had eGFR slopes $\geq-2 \mathrm{~mL} / \mathrm{min} /$ $1.73 \mathrm{~m}^{2} /$ year (table 3 ). The open box represents 12 participants who met the UPCR goal but had eGFR slope was $<-2 \mathrm{~mL} / \mathrm{min} /$ $1.73 \mathrm{~m}^{2} /$ year $(-4.2$ (95\% CI -5.3 to -3.6$) \mathrm{mL} / \mathrm{min} / 1.73 \mathrm{~m}^{2}$ / year)). The 12 participants who met the UCPR goal, but with significant decline in kidney function (eGFR slope $<-2.0 \mathrm{~mL} /$ $\mathrm{min} / 1.73 \mathrm{~m}^{2} /$ year) had greater UPCR and ACR during the treatment period than did those who met the UCPR goal and had preserved kidney function (table 3).

For the group of six participants that did not meet the UPCR goal (open box), the slope was $-7.0(95 \% \mathrm{CI}-9.0$ to -5.6$) \mathrm{mL} /$ $\mathrm{min} / 1.73 \mathrm{~m}^{2} /$ year; none of them had an eGFR slope $>-2 \mathrm{~mL} /$ $\min / 1.73 \mathrm{~m}^{2} /$ year. The group of six who met the UPCR goal and had preserved renal function (eGFR slope $>-2 \mathrm{~mL} / \mathrm{min} /$
$1.73 \mathrm{~m}^{2}$ ) received significantly fewer medications than the other groups (table 3 ).

Poisson regression analysis was done for the 18 participants who met the UPCR goal, stratified by eGFR slope $>-2.0$ or $\leq 2.0 \mathrm{~mL} / \mathrm{min} / 1.73 \mathrm{~m}^{2} /$ year (table 4 ).

Univariate analysis was carried out for each of the average values of the predictor variables shown in table 3 . The variables included in the final model were age at which ERT was started, duration of ERT treatment before enrolment, average systolic blood pressure during the treatment phase, average UPCR during the treatment phase, gender and medication score. The only significant predictor of preserved kidney function was the age at which agalsidase-beta treatment was started. The median age at which ERT was started for the six patients who had eGFR slope $>-2.0 \mathrm{~mL} / \mathrm{min} / 1.73 \mathrm{~m}^{2}$ was $37.9(30.3-46.1)$ years and 45.1 (40.4-49.2) years (table 3 ).

\section{Adverse events}

Online supplementary table 3 summarises the participants by UPCR goal and eGFR slope. Hyperkalaemia (>5.5 mEq/L) occurring in seven participants was managed with dietary modification and reduction in ACE inhibitor or ARB dose. Hypotension also occurred in other eight participants and was managed with dosing modification. There were not any serious consequences attributed at the study sites to hyperkalaemia or hypotension.
Figure 2 Box plots of Chronic Kidney Disease Epidemiology Collaboration estimated glomerular filtration rate (eGFR) slopes. (A) Stratified at urine protein to creatinine ratio (UPCR) goal. (B) Stratified by eGFR slope at $-2.0 \mathrm{~mL} / \mathrm{min}$ per $1.73 \mathrm{~m}^{2} /$ year. The UPCR goal was defined as UPCR for first treatment visit $\leq 0.5 \mathrm{~g} / \mathrm{g}$, or averaged treatment UPCR $\leq 50 \%$ of baseline UPCR (visit -3 ), or averaged treatment UPCR $<0.5 \mathrm{~g} / \mathrm{g}$. The eGFR slopes and intercepts were calculated with a mixed-effect linear model across all treatment visits. eGFR slopes, $\mathrm{mL} / \mathrm{min} / 1.73 \mathrm{~m}^{2} / y e a r$. The horizontal line is the median value and the upper and lower limits of the boxes are 75th and 25th centiles, respectively. The number of participants in each category is shown in parentheses above the upper cap of the 90th centile values.
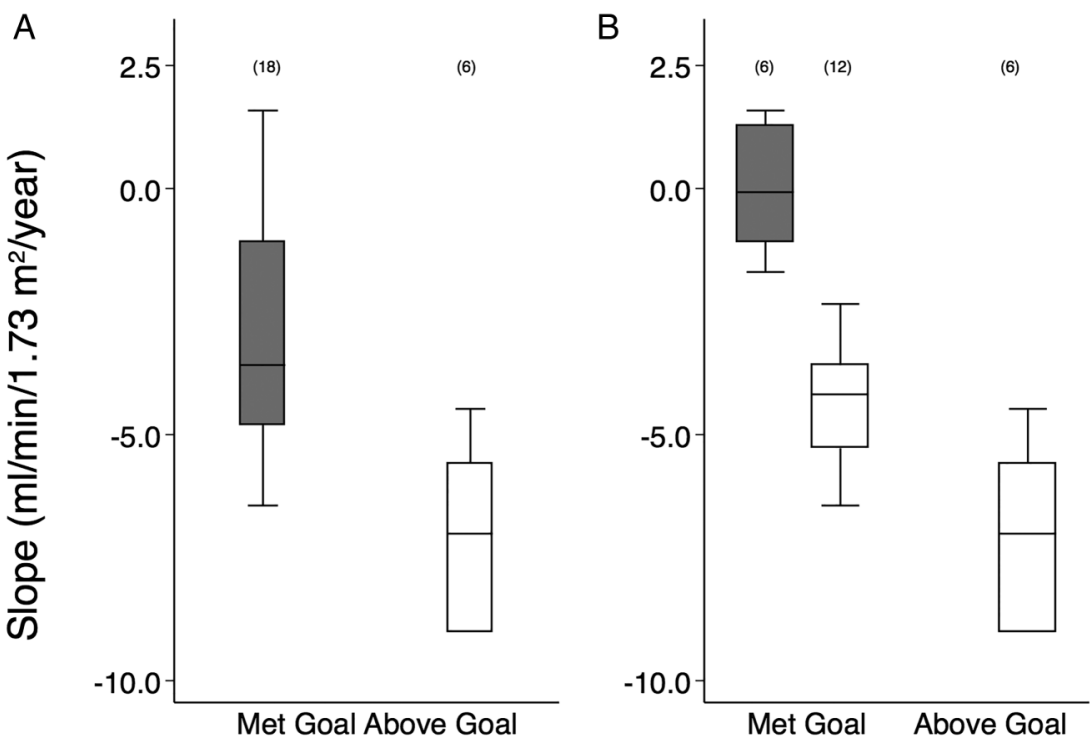
Table 3 Characteristics for all participants: stratified by UPCR goal and eGFR slope at $-2.0 \mathrm{~mL} / \mathrm{min} / 1.73 \mathrm{~m}^{2} /$ year

\begin{tabular}{|c|c|c|c|}
\hline Variable & Met UPCR goal (18) & & Above UPCR goal (6) \\
\hline eGFR slope strata (mL/min $/ 1.73 \mathrm{~m}^{2} /$ year): $\mathrm{N}$ & $(\geq-2.0): 6$ & $(<-2.0): 12$ & $(<-2.0): 6$ \\
\hline Age at visit 0 (year) & $40.6(30.9-51.8)$ & $46.6(42.9-51.3)$ & $41.5(35.1-51.7)$ \\
\hline Age: ERT started (years) & $37.9(30.3-46.1)$ & $45.1(40.4-49.2)$ & $37.2(33.5-47.2)$ \\
\hline Interval: ERT start to visit 0 (years) & $5.1(0.4-5.5)$ & $2.6(0.3-4.1)$ & $3.6(1.4-4.1)$ \\
\hline \multicolumn{4}{|l|}{ Initial follow-up (visit 0) } \\
\hline Systolic blood pressure $(\mathrm{mm} \mathrm{Hg})$ & $101(98-107)$ & $112(109-126)$ & $111(100-120)$ \\
\hline Serum $\mathrm{K}^{+}(\mathrm{mEq} / \mathrm{L})$ & $4.2(3.7-5.0)$ & $4.2(4.0-4.6)$ & $4.2(3.9-5.2)$ \\
\hline UPCR $(g / g)$ & $0.1(0.1-0.3)$ & $0.3(0.2-0.9)$ & $0.9(0.7-1.7)$ \\
\hline $\mathrm{ACR}(\mathrm{mg} / \mathrm{g})$ & $61(5.7-96)$ & $162(69-598)$ & $627(456-1126)$ \\
\hline eGFR $\left(\mathrm{mL} / \mathrm{min} / 1.73 \mathrm{~m}^{2}\right)$ & $88(56-116)$ & $62(48-78)$ & $61(45-81)$ \\
\hline \multicolumn{4}{|l|}{ Average of follow-up visits } \\
\hline Systolic blood pressure $(\mathrm{mm} \mathrm{Hg})$ & $104(102-111)$ & $119(107-130)$ & $112(107-117)$ \\
\hline Serum $\mathrm{K}^{+}(\mathrm{mEq} / \mathrm{L})$ & $4.8(4.0-5.6)$ & $4.9(4.7-5.2)$ & $4.9(4.0-5.5)$ \\
\hline UPCR $(g / g)$ & $0.3(0.1-0.5)$ & $0.4(0.3-0.7)$ & $0.9(0.7-1.5)$ \\
\hline ACR $(\mathrm{mg} / \mathrm{g})$ & $122(18-234)$ & $254(123-491)$ & $579(454-733)$ \\
\hline eGFR $\left(\mathrm{mL} / \mathrm{min} / 1.73 \mathrm{~m}^{2}\right)$ & $80(75-126)$ & $56(45-75)$ & $68(45-73)$ \\
\hline \multicolumn{4}{|l|}{ Last follow-up visit } \\
\hline Systolic blood pressure $(\mathrm{mm} \mathrm{Hg})$ & $110(101-118)$ & $120(113-140)$ & $111(101-120)$ \\
\hline Serum $\mathrm{K}^{+}(\mathrm{mEq} / \mathrm{L})$ & $4.1(3.9-4.9)$ & $4.5(4.0-4.7)$ & $4.6(3.8-4.8)$ \\
\hline UPCR $(g / g)$ & $0.3(0.1-0.7)$ & $0.3(0.2-1.0)$ & $1.0(0.8-1.7)$ \\
\hline $\mathrm{ACR}(\mathrm{mg} / \mathrm{g})$ & $67(8.4-481)$ & $198(73-962)$ & 719 (533-1196) \\
\hline eGFR $\left(\mathrm{mL} / \mathrm{min} / 1.73 \mathrm{~m}^{2}\right)$ & $97(75-121)$ & $62(51-85)$ & $47(35-90)$ \\
\hline Medication score & $1.5(1-2)$ & $3(2-3)$ & $3(3-3)$ \\
\hline eGFR slope (mL/min $/ 1.73 \mathrm{~m}^{2} /$ year) & $-0.1(-1.1$ to 1.3$)$ & $-4.2(-5.3$ to -3.6$)$ & $-7.0(-9.0$ to -5.6$)$ \\
\hline eGFR intercept $\left(\mathrm{mL} / \mathrm{min} / 1.73 \mathrm{~m}^{2}\right)$ & $90(70-124)$ & $63(50-80)$ & $56(45-82)$ \\
\hline
\end{tabular}

Continuous variables presented as median (25th-75th centile). Medication score defined as: 0 , none; 1 , ACE inhibitor or ARB; 2 , ACE inhibitor plus ARB, or diuretic; 3 , ACE inhibitor or $\mathrm{ARB}$ at maximum dose.

$p<0.05$ for differences in medians, comparing groups to reference (met UPCR goal and slope $-2.0 \mathrm{~mL} / \mathrm{min} .1 .73 \mathrm{~m}^{2} /$ year); with two-sample Wilcoxon rank-sum test (shown in bold). UPCR goal defined as UPCR at first treatment visit $\leq 0.5 \mathrm{~g} / \mathrm{g}$, or averaged treatment UPCR $\leq 50 \%$ of baseline UPCR (visit-3), or averaged treatment UPCR $<0.5 \mathrm{~g} / \mathrm{g}$. ARB, angiotensin type 1 receptor blocker; $A C R$, albumin to creatinine ratio; eGFR, estimated glomerular filtration rate; ERT, enzyme replacement therapy; UPCR, urinary protein to creatinine ratio ( $g / g$ ).

\section{DISCUSSION}

Seventy-five per cent of FAACET participants receiving agalsidase-beta treatment at $1 \mathrm{mg} / \mathrm{kg}$ every other week achieved the UPCR goal with manageable side effects during treatment with antiproteinuric agents. These patients had severe Fabry disease with overt proteinuria and cardiac involvement (online supplementary table 2). Control of UCPR to the a priori treatment goal was associated with a rate of eGFR decline of $-3.6 \mathrm{~mL} / \mathrm{min} / 1.73 \mathrm{~m}^{2} /$ year compared with $-7.0 \mathrm{~mL} / \mathrm{min} /$

Table 4 Poisson regression analysis of eGFR slope at $-2.0 \mathrm{~mL}$ / $\mathrm{min} / 1.73 \mathrm{~m}^{2} /$ year for 18 participants who met the UCPR goal

\begin{tabular}{|c|c|c|c|}
\hline Variable & $\begin{array}{l}\text { Relative } \\
\text { risk }\end{array}$ & $95 \% \mathrm{Cl}$ & $p$ Value \\
\hline Age: ERT started (years) & 1.072 & 1.008 to 1.139 & 0.026 \\
\hline Interval: ERT start to visit 0 (years) & 0.881 & 0.771 to 1.006 & 0.062 \\
\hline Average systolic blood pressure (mm Hg) & 1.011 & 0.991 to 1.033 & 0.287 \\
\hline Average UPCR during treatment $(\mathrm{mg} / \mathrm{g})$ & 1.479 & 0.630 to 3.468 & 0.369 \\
\hline Male gender & 1.130 & 0.637 to 2.005 & 0.675 \\
\hline Medication score & 1.392 & 0.859 to 2.254 & 0.179 \\
\hline \multicolumn{4}{|c|}{$\begin{array}{l}\text { Relative risk presented as ratios }(95 \% \mathrm{Cl}) \text {. Medication score defined as: } 0 \text {, none; } 1 \text {, } \\
\text { ACE inhibitor or ARB; } 2 \text {, ACE inhibitor plus ARB, or diuretic; 3, ACE inhibitor or ARB } \\
\text { at maximum dose. } p<0.05 \text { for risk ratios from Poisson regression model (shown in } \\
\text { bold). } \\
\text { ARB, angiotensin type } 1 \text { receptor blocker; eGFR, estimated glomerular filtration rate; } \\
\text { ERT, enzyme replacement therapy; UPCR, urinary protein to creatinine ratio }(\mathrm{g} / \mathrm{g}) \text {. }\end{array}$} \\
\hline
\end{tabular}

$1.73 \mathrm{~m}^{2} /$ year for the participants that did not meet the UPCR treatment goal.

Previous descriptions of classical Fabry treated with agalsidase-beta but for whom urinary protein excretion was not controlled reported rates of eGFR decline that were similar to the FAACET participants who did not meet the UPCR goal. $^{11} 13 \quad 1920$ A previous single-centre experience reported that control of UPCR to a goal of $<0.5 \mathrm{~g} / \mathrm{g}$ in seven patients (six males and one female) with severe Fabry nephropathy was associated with stabilisation of kidney function in six patients (median slope $-0.23 \mathrm{~mL} / \mathrm{min} / 1.73 \mathrm{~m}^{2} /$ year), ${ }^{14}$ similar to the eGFR slope observed in six participants in the current trial who met the UPCR goal and had stabilisation of their renal function. In contrast, one patient in the previous study did not have kidney function stabilisation despite control of the UPCR. ${ }^{14}$

Germain $e t a l^{12}$ recently published a 10 -year follow-up of the original phase III cohort treated with agalsidase-beta. Several important points emerged from that analysis, which are confirmed by the present findings. Disease progression rates for patients with low renal involvement (LRI, $n=32$ ) or high renal involvement (HRI, $n=20$ ) at baseline were assessed, where the LRI group had average UPCR identical to the UPCR goal in the current study. The HRI group had UPCR $>1.0 \mathrm{~g} / \mathrm{g}$ at baseline as well as significant degree of glomerular sclerosis at baseline renal biopsy. ${ }^{11} 12$ Patients in the LRI group (mean age 25 years at baseline) experienced some loss of eGFR $(-1.89 \mathrm{~mL} / \mathrm{min} /$ $1.73 \mathrm{~m}^{2} /$ year) over the 10 -year follow-up. Renal disease progression seems to be related, at least in part, to the severity of the disease before treatment. LRI patients with UPCR $\leq 0.5 \mathrm{~g} / \mathrm{g}$ 
throughout the treatment period progressed at a slower rate compared with HRI patients with UPCR $>0.5 \mathrm{~g} / \mathrm{g}$ during the treatment period. HRI patients began treatment with agalsidasebeta at a mean age of 38 years, and rates of decline in kidney function (eGFR slope: $-6.82 \mathrm{~mL} / \mathrm{min} / 1.73 \mathrm{~m}^{2} /$ year) that were similar to the six participants in the current report that did not meet the UPCR goal. These results support the recommendation that agalsidase-beta therapy be started before there is significant structural damage, including podocyte loss, glomerulosclerosis, interstitial fibrosis and proteinuria. ${ }^{21}{ }^{22}$ More aggressive approaches have been tried to control the proteinuria in highrisk group Fabry patients, ${ }^{23}{ }^{24}$ including the use of weekly rather than every other week ERT dosing. ${ }^{25}$ In addition, neutralising antibodies directed against agalsidase-beta may be another factor that may limit the success in controlling proteinuria and/ or stabilising renal function. ${ }^{26}$

The importance of the age at which ERT is initiated was recently emphasised ${ }^{12}$ and is confirmed by the present findings, suggesting that severe underlying changes in renal structure ${ }^{21}$ may limit the beneficial effects of controlling urine protein excretion. Regression analysis (table 4) showed that the age at which ERT was started was the only significant factor associated with risk of renal progression in patients for whom ACE inhibitor or ARB therapy controlled the average UPCR to $\leq 0.5 \mathrm{~g} / \mathrm{g}$, thus confirming and extending the recent report from Germain et al. ${ }^{12}$

The eGFR slope was significantly worse in the six patients who did not achieve the goal for controlling proteinuria using ACE inhibitor and/or ARB (table 1). Alternative approaches could be considered for these patients, ${ }^{23}{ }^{24}$ as well as directly assessing the severity of the renal pathology. Endothelial dysfunction ${ }^{27}$ and autonomic insufficiency ${ }^{28}$ are features of classical Fabry disease, which may explain why some patients had treatment-related side effects with antiproteinuria agents. Despite these side effects, control of proteinuria to the target was achieved in 18/24 patients in the study. The treatment goal for controlling proteinuria to $0.5 \mathrm{~g} / \mathrm{day}$ was based on a meta-analysis of non-Fabry patients with proteinuria and chronic kidney disease. ${ }^{29}$ Current consensus is lacking about the treatment goal for controlling proteinuria in any form of chronic kidney disease; recent experiences with aggressive treatment regimens with combined agents in type 2 diabetes have been disappointing. ${ }^{30}$

There are important limitations of the FAACET study, including non-randomised study design, lack of a washout period for antiproteinuric therapy before enrolment, lack of a concurrent control group, an open-label study design and the use of historical values for defining eligibility for the study. There was not a uniform approach to the use of antiproteinuric agents, which reflected the standard of care at each study site. None of the participants had baseline renal biopsies to assess the severity of baseline kidney involvement, but based on their baseline eGFR and urine protein measurements, both males and females had severe kidney disease at the time of enrolment. ${ }^{19}$ In view of the lifelong burden of Fabry disease, the short-term follow-up in the present study is an important limitation to keep in mind.

In summary, urine protein excretion can be controlled in the majority of classical Fabry patients with antiproteinuric therapy. Kidney function was not preserved in patients who did not achieve the UPCR treatment goal. Stabilisation of kidney function was only achieved in a minority of patients who were younger at the time they started ERT. Careful dose titration is needed to avoid adverse effects that included hypotension and hyperkalaemia, similar to other forms of advanced kidney disease.
Acknowledgements The authors thank the patients and investigators who participated in the FAACET study.

Collaborators FAACET Investigators.

Contributors All of the authors were involved in the initial concept of the manuscript and have reviewed and commented on all drafts and data. DGW had full access to the data, performed the statistical analyses, wrote the initial draft and had final responsibility for the decision to submit for publication.

Funding Genzyme, a Sanofi company, the FAACET Study, as an investigator Sponsored Study to the University of Alabama at Birmingham (DGW, principal investigator). Genzyme also funds the Fabry Registry.

Competing interests Members of the Fabry Registry Board of Advisors (receiving expense reimbursement from Genzyme) include DGW, BV, JC, DAL, WRW and CW. The authors who have received research funds, travel support or speaking fees from Genzyme include DGW, BV, JC, DAL, WRW and CW. DGW has received consulting fees from Genzyme, Shire HGT and Amicus Therapeutics. JC has received consulting fees from Shire HGT, BioMarin and Protalix Corporation. WRW has served as a paid consultant to Amicus Therapeutics and Shire HGT.

Patient consent All patients provided written informed consent before enrolment. Patient participation in the Fabry Registry (NCT00196742) is voluntary. Each independent site was responsible for obtaining informed consent to submit and enter data into the Fabry Registry..

Ethics approval The institutional review boards approved the FAACET trial at each study site (NCT00446862), which complied with the Declaration of Helsinki.

Provenance and peer review Not commissioned; externally peer reviewed.

Data sharing statement Data files and analytic files are available upon request.

Open Access This is an Open Access article distributed in accordance with the Creative Commons Attribution Non Commercial (CC BY-NC 4.0) license, which permits others to distribute, remix, adapt, build upon this work non-commercially, and license their derivative works on different terms, provided the original work is properly cited and the use is non-commercial. See: http://creativecommons.org/ licenses/by-nc/4.0/

\section{REFERENCES}

1 Desnick RJ, loannou YA, Eng CM. Alpha-galactosidase A deficiency: fabry disease In: Scriver C, Beaudet A, Sly W, et al, eds. The metabolic bases of inherited disease. 8th edn. New York: McGraw-Hill, 2001:3733-74.

2 Germain DP. Fabry disease. Orphanet J Rare Dis 2010;5:30.

3 Wilcox WR, Oliveira JP, Hopkin RJ, Ortiz A, Banikazemi M, Feldt-Rasmussen U, Sims K, Waldek S, Pastores GM, Lee P, Eng CM, Marodi L, Stanford KE, Breunig F, Wanner C, Warnock DG, Lemay RM, Germain DP. Females with Fabry disease frequently have major organ involvement: Lessons from the Fabry Registry. $\mathrm{Mol}$ Genet Metab 2008;93:112-28.

4 Ortiz A, Oliveira JP, Waldek S, Warnock DG, Cianciaruso B, Wanner C. Nephropathy in males and females with Fabry disease: cross-sectional description of patients before treatment with enzyme replacement therapy. Nephrol Dial Transplant 2008;23:1600-7.

5 Dobrovolny R, Dvorakova L, Ledvinova J, Magage S, Bultas J, Lubanda JC, Elleder M, Karetova D, Pavlikova M, Hrebicek M. Relationship between X-inactivation and clinical involvement in Fabry heterozygotes. Eleven novel mutations in the alpha-galactosidase A gene in the Czech and Slovak population. J Mol Med 2005;83:647-54.

6 Echevarria L, Benistan K, Toussaint A, Dubourg O, Hagege AA, Eladari D, Jabbour F, Beldjord C, De Mazancourt P, Germain DP. X-chromosome inactivation in female patients with Fabry disease. Clin Genet 2015. doi: 10.1111/cge.12613

7 Waldek S, Patel MR, Banikazemi M, Lemay R, Lee P. Life expectancy and cause of death in males and females with Fabry disease: findings from the Fabry Registry. Genet Med 2009;11:790-6.

8 Mehta A, Clarke JT, Giugliani R, Elliott P, Linhart A, Beck M, Sunder-Plassmann G. Natural course of Fabry disease: changing pattern of causes of death in FOS-Fabry Outcome Survey. J Med Genet 2009;46:548-52.

9 Eng CM, Guffon N, Wilcox WR, Germain DP, Lee P, Waldek S, Caplan L, Linthorst GE, Desnick RJ. Safety and efficacy of recombinant human alpha-galactosidase A--replacement therapy in Fabry's disease. N Engl J Med 2001;345:9-16.

10 Thurberg BL, Rennke H, Colvin RB, Dikman S, Gordon RE, Collins AB, Desnick RJ, $O^{\prime}$ Callaghan M. Globotriaosylceramide accumulation in the Fabry kidney is cleared from multiple cell types after enzyme replacement therapy. Kidney Int 2002:62:1933-46.

11 Germain D, Waldek S, Banikazemi M, Bushinsky D, Charrow J, Lee P, Loew T, Vedder AC, Abichandani R, Wilcox WR, Guffon N. Sustained, long-term renal stabilization after 54 months of agalsidase beta therapy in patients with Fabry disease. J Am Soc Nephrol 2007;18:1547-57.

12 Germain DP, Charrow J, Desnick RJ, Guffon N, Kempf J, Lachmann RH, Lemay R, Linthorst GE, Packman S, Scott CR, Waldek S, Warnock DG, Weinreb NJ, Wilcox 
WR. Ten-year outcome of enzyme replacement therapy with agalsidase beta in patients with Fabry disease. J Med Genet 2015;52:353-8.

13 Banikazemi M, Bultas J, Waldek S, Wilcox WR, Whitley CB, McDonald M, Finkel R, Packman S, Bichet DG, Warnock DG, Desnick RJ. Agalsidase-beta therapy for advanced Fabry disease: a randomized trial. Ann Intern Med 2007;146: 77-86.

14 Tahir H, Jackson LL, Warnock DG. Antiproteinuric therapy and Fabry nephropathy: Sustained reduction in proteinuria in patients receiving enzyme replacement therapy with agalsidase-beta. J Am Soc Nephrol 2007;18:2609-17.

15 Schiffmann R, Warnock DG, Banikazemi M, Bultas J, Linthorst GE, Packman S, Sorensen SA, Wilcox WR, Desnick RJ. Fabry disease: progression of nephropathy, and prevalence of cardiac and cerebrovascular events before enzyme replacement therapy. Nephrol Dial Transplant 2009;24:2102-11.

16 Wanner C, Oliveira JP, Ortiz A, Mauer M, Germain DP, Linthorst GE, Serra AL, Marodi L, Mignani R, Cianciaruso B, Vujkovac B, Lemay R, Beitner-Johnson D, Waldek $S$, Warnock DG. Prognostic indicators of renal disease progression in adults with fabry disease: natural history data from the fabry registry. Clin J Am Soc Nephrol 2010;5:2220-8.

17 Stevens LA, Coresh J, Greene T, Levey AS. Assessing kidney function--measured and estimated glomerular filtration rate. N Engl J Med 2006;354:2473-83.

18 Levey AS, Coresh J, Greene T, Marsh J, Stevens LA, Kusek JW, Van Lente F. Expressing the modification of diet in renal disease study equation for estimating glomerular filtration rate with standardized serum creatinine values. Clin Chem 2007:53:766-72.

19 Warnock DG, Ortiz A, Mauer M, Linthorst GE, Oliveira JP, Serra AL, Marodi L, Mignani R, Vujkovac B, Beitner-Johnson D, Lemay R, Cole JA, Svarstad E, Waldek S, Germain DP, Wanner C, Fabry R. Renal outcomes of agalsidase beta treatment for Fabry disease: role of proteinuria and timing of treatment initiation. Nephrol Dial Transplant 2012;27:1042-9.

20 Weidemann F, Niemann M, Stork S, Breunig F, Beer M, Sommer C, Herrmann S, Ertl G, Wanner C. Long-term outcome of enzyme-replacement therapy in advanced Fabry disease: evidence for disease progression towards serious complications. J Intern Med 2013;274:331-41.
21 Fogo AB, Bostad L, Svarstad E, Cook WJ, Moll S, Barbey F, Geldenhuys L, West M, Ferluga D, Vujkovac B, Howie AJ, Burns A, Reeve R, Waldek S, Noel LH, Grunfeld JP, Valbuena C, Oliveira JP, Muller J, Breunig F, Zhang X, Warnock DG. Scoring system for renal pathology in Fabry disease: report of the International Study Group of Fabry Nephropathy (ISGFN). Nephrol Dial Transplant 2010;25:2168-77.

22 Tondel C, Kanai T, Larsen KK, Ito S, Politei JM, Warnock DG, Svarstad E. Foot process effacement is an early marker of nephropathy in young classic fabry patients without albuminuria. Nephron Physiol 2015;129:16-21.

23 Trimarchi H, Forrester M, Lombi F, Pomeranz V, Rana MS, Karl A, Andrews J. Amiloride as an alternate adjuvant antiproteinuric agent in fabry disease: the potential roles of plasmin and uPAR. Case Rep Nephrol 2014;2014:854521.

24 Pisani A, Sabbatini M, Duro G, Colomba P, Riccio E. Antiproteinuric effect of add-on paricalcitol in Fabry disease patients: a prospective observational study. Nephrol Dial Transplant 2015;30:661-6.

25 Schiffmann R, Swift C, Wang X, Blankenship D, Ries M. A prospective 10-year study of individualized, intensified enzyme replacement therapy in advanced Fabry disease. J Inher Metab Dis 2015. doi: 10.1007/s10545-015-9845-5

26 Lenders M, Stypmann J, Duning T, Schmitz B, Brand SM, Brand E. Serum-mediated inhibition of enzyme replacement therapy in fabry disease. J Am Soc Nephrol 2015. doi: 10.1681/ASN.2014121226

27 Shen JS, Meng XL, Moore DF, Quirk JM, Shayman JA, Schiffmann R, Kaneski CR. Globotriaosylceramide induces oxidative stress and up-regulates cell adhesion molecule expression in Fabry disease endothelial cells. Mol Genet Metab 2008;95:163-8

28 Hilz MJ, Marthol H, Schwab S, Kolodny EH, Brys M, Stemper B. Enzyme replacement therapy improves cardiovascular responses to orthostatic challenge in Fabry patients. J Hypertens 2010;28:1438-48.

29 Kent DM, Jafar TH, Hayward RA, Tighiouart $H$, Landa M, de Jong P, de Zeeuw D, Remuzzi G, Kamper AL, Levey AS. Progression risk, urinary protein excretion, and treatment effects of Angiotensin-converting enzyme inhibitors in nondiabetic kidney disease. J Am Soc Nephrol 2007;18:1959-65.

30 Luft FC. Perspective on combination RAS blocking therapy: off-TARGET, dis-CORD, MAP-to-nowhere, low ALTITUDE, and NEPHRON-D. Am J Nephrol 2014;39:46-9. 